J. Phytopathology 136, 238-246 (1992)

(c) 1992 Paul Parey Scientific Publishers, Berlin and Hamburg

ISSN $0931-1785$

Faculté des Sciences Agronomiques, 5030 Gembloux, Belgium

\title{
Effects of Commercial Fatty Acids on Cutinase Release by Ascochyta pisi
}

\author{
B. Nasraoui, P. Lepoivre and J. Semal
}

Authors' addresses: B. NAsRAour, Ecole Supérieure d'Agriculture, 7119 le Kef, Tunisia. Authors' addresses: B. Nasraout, Ecole Superieure d'Agriculture,
P. Leporvre and J. Semal, Faculté des Sciences Agronomiques, 5030 Gembloux, Belgium.

With 7 figures

Received October 1, 1991; accepted December 12, 1991

\section{Abstract}

The effect of a range of commercially available $\mathrm{C}_{16}$ and $\mathrm{C}_{18}$ fatty acids, on the release of cutinase by Ascochyta pisi, was studied. When juniperic acid was used as sole carbon source, cutinase activity by with acetone used as enzyme extractor. Without acetone, less cutinase was naturally released in culture medium containing juniperic acid at $0.5 \%$, than at $0.01 \%$ or $0.05 \%$. Upon post-treatment with acetone, the same level of cutinase was released with all three concentrations, thus suggesting that the enzyme was induced, but not completely released in the presence of $0.5 \%$ juniperic acid. When ricinelaidic or ricinoleic acids were supplemented at $0.5 \%$ to cutin in the culture medium, they strongly inhibited the release of cutinase, even with acetone post-treatment. Comparable inhibition by ricin wased as cutinase inducer, thus suggesting that not only the release, but also the production of cutinase were inhibited.

\section{Zusammenfassung}

Einflïsse von käuflichen Fettsäuren auf die Cutinasefreisetzung durch Ascochyta pisi

Untersucht wurde der Einfluß von käuflichen $C_{16}$ - und $C_{18}$-Fettsäuren auf die Freisetzung von Cutinase durch Ascochyta pisi. Wenn Junipersäure als einzige Kohlenstoffquelle vorhanden war, wurde Cutinase in das Kulturmedium freigesetzt, und dies wurde durch eine Nachbehandlung der A. pisi-Kulturen mit Aceton, als Enzymextraktor, stark erhöht. Ohne die Acetonbehandlung wurde weniger Cutinase in das Kulturmedium freigesetzt, wenn Junipersäure in einer Konzentration von $0,5 \%$ statt $0,01 \%$ oder $0,05 \%$ vorhanden war. Nach einer Acetonnachbehandlung jedoch wurde die gleiche Cutinasemenge bei allen Konzentrationen freigesetzt, was darauf hindeutet, daß das Enzym induziert, aber im Vorhandensein von $0,5 \%$ Junipersäure nicht vollständig freigesetzt war.

US. Copyright Clearance Center Code Statement: 0931-1785/92/3603-0238\$02.50/0 
Wenn $0,5 \%$ Ricinelaid- oder Ricinolsäure Cutin im Kulturmedium beigemischt wurde, wurde die Freisetzung von Cutinase stark gehemmt, auch nach einer Acetonnachbehandlung. Auch wenn Junipersäure als Cutinaseinduzierer verwendet wurde, wurde eine gleiche, durch Ricinolsäure verursachte Hemmung beobachtet. Dies deutet darauf hin, daß nicht nur die Freisetzung, sondern auch die Produktion von Cutinase gehemmt wurde.

Cutinase is an esterase able to hydrolyze cutin, a polymer of $\mathrm{C}_{16}$ and $\mathrm{C}_{18}$ fatty acids which is the main component of plant cuticle. Cutinase is produced by some fungi during their penetration in the host-plant. The most important works concerning this subject were summarized by KOLATtukUdy (1985) and KöLleR (1991).

Cutinase is known to be induced in fungi by using cutin as sole source of carbon. Fungal cutinase was also induced by low concentrations of fatty acids extracted from hydrolyzed cutin (LIN and KolatTukudy 1978, Woloshuk and Kolattukudy 1986, Podila et al. 1988); its activity was severely inhibited by reagents directed towards active serine, such as diisopropyl fluorophosphate (DFP) (Purdy and Kolattukudy 1975).

In a previous paper (NASRAOUI et al. 1990), we have shown that two pea pathogens, Mycosphaerella pinodes (Berk. \& Blox.) Vestergr. [Ascochyta pinodes Jones], and Ascochyta pisi Lib., released cutinase activity when grown in a medium containing cutin as sole source of carbon; this cutinase was involved in the successful infection of the host.

In the present work, we studied the effects of some commercial $\mathrm{C}_{16}$ and $\mathrm{C}_{18}$ fatty acids on in vitro release of cutinase by $A$. pisi.

\section{Materials and Methods}

\section{Growth conditions}

Spore suspensions of A. pisi (strain LG, kindly donated by Dr SPIRE, INRA, France) were Spot in the culture media (described in Cutinase induction paragraph) in Erlenmeyer flasks, to submersed in the culals were incubated on a rotary reach a final volume of $10 \mathrm{ml}$ containing $5 \times 10^{3}$ spores $/ \mathrm{ml}$. The rials were incubated on a rotary shaker at $26^{\circ} \mathrm{C}$, with a photoperiod of $16 \mathrm{~h}$ light.

For cutinase activity measurement, A. pisi cultures of 15 days were filtered; filtrates were collected and mycelium was resuspended in tresh mineral solution of a modified Czapeck-Dox's medium (DiCKMAN and PATIL 1986) containing 20\% (v/v) of acetone used as potential enzyme extras

For esterase activity measurements, $A$. pisi cultures were incubated for 24 to $72 \mathrm{~h}$. At the end of incubation period, distlled water, or acetone used as enzyme extractor, were added $(20 \% \mathrm{v} / \mathrm{v})$. Incubation was continued for $2 \mathrm{~h}$, and cultures were finally filtered to discard the mycelium.

\section{Cutinase induction}

To induce cutinase, the mineral solution of the modified Czapeck-Dox's medium (DickMaN PATIL 1986) was neutralized to $\mathrm{pH} 7$ with phosphoric acid, and was supplemented with $0.2 \%$ (w) v) cutin and/or different concentrations of the following commercially available $\mathrm{C}_{16}$ and $\mathrm{C}_{18}$ fatty acids:

- palmitic acid (hexadecanoic acid) from Sigma,

- juniperic acid (16-hydroxyhexadecanoic acid) from Aldrich-Chemie,

- stearic acid (octadecanoic acid) from Sigma, 
- 12-hydroxystearic acid (DL-12-hydroxyoctadecanoic acid) from Aldrich-Chemie,

- ricinelaidic acid ([+]-12-hydroxy-trans-9-octadecenoic acid) from Sigma,

- ricinoleic acid ([R]-12-hydroxy-cis-9-octadecenoic acid) from Sigma.

Cutin was purified from peelings of apples cv. "Golden Delicious", as described by BAKER and BATEMAN (1978). The mineral solution was used as cutinless control medium. All media were autoclaved for $20 \mathrm{~min}$ at $120^{\circ} \mathrm{C}$.

\section{Cutinase activity}

Cutinase activity released by $A$. pisi was measured by microtitration of the fatty acids released from a cutin substrate. This method was used with $A$. pisi grown on medium containing juniperic acid as sole source of carbon. A. pisi culture filtrates were dialysed for $48 \mathrm{~h}$ against distilled water, and lyophilized. Lyophilized filtrates were incubated for $24 \mathrm{~h}$ at $35^{\circ} \mathrm{C}$ in the cutin reaction medium of BASHAN et al. (1985), made of $2 \mathrm{ml}$ of $1 \mathrm{mM}$ phosphate buffer $\mathrm{pH} 7,1 \mathrm{ml}$ of cutin suspension at $10 \mathrm{mg} / \mathrm{ml}$, and a drop of toluene. The reaction medium was supplemented or not with $10 \mathrm{mM}$ diisopropyl fluorophosphate (DFP), a cutinase activity inhibitor (PURDY and KOLATTUKUDY 1975), and was incubated for $24 \mathrm{~h}$. It was then filtered, and $\mathrm{pH}$ of the filtrate was adjusted to 3.5 with phosphoric acid.

Fatty acids in the filtrate $(3 \mathrm{ml})$ were extracted 3 times with diethyl ether, followed by evaporation under vacuum. They were then dissolved in methanol and titrated with $\mathrm{NaOH}$ (from the initial $\mathrm{pH}$ up to $\mathrm{pH}$ 8.2). Palmitic acid was used as standard, and cutinase activity was expressed as units $(\mathrm{U}) / \mathrm{ml}$ of filtrate ( $1 \mathrm{U}=1 \mu \mathrm{g}$ of palmitic acid equivalent/h).

\section{Esterase activity}

Cutinase is also evaluated by measuring esterase activity, using para-nitrophenyl esters as model substrate (KOLATTUKUDY 1985). In the present work, we evaluated esterase activity using paranitrophenylbutyrate (PNPB) as substrate and para-nitrophenol (PNP) as final product, as revealed by measuring absorbance at $400 \mathrm{~nm}$. The enzymatic reaction was carried out in $7 \mathrm{ml}$ of $30 \mathrm{mM}$ phosphate buffer $\mathrm{pH} \mathrm{7,} \mathrm{mixed} \mathrm{with} 1 \mathrm{ml}$ of $A$. pisi culture filtrate and $2 \mathrm{ml}$ of $1 \mathrm{mM} \mathrm{PNPB}$ in the phosphate buffer (PARKKINEN et al. 1978). Esterase activity was expressed as units (U)/ml of filtrate (1 $\mathrm{U}=1 \mu \mathrm{M}$ $\mathrm{PNP} / \mathrm{min}$ ).

\section{Results}

Induction of esterase activity with fatty acids

Among the fatty acids used at $0.05 \%$ or $0.5 \%$ as sole source of carbon, juniperic acid proved to be the only powerful inducer of esterase activity release

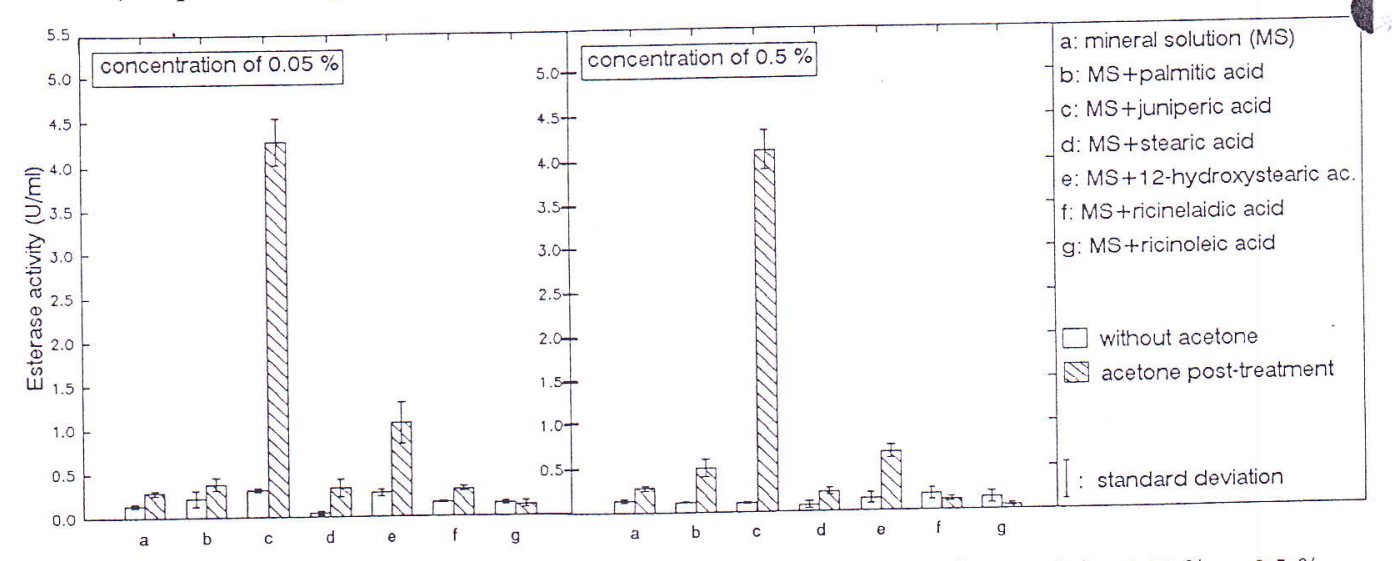

Fig. 1. Esterase activity released by $A$. pisi after 24 h of culture in media containing $0.05 \%$ or $0.5 \%$ of different fatty acids used as sole carbon source, followed or not by acetone post-treatment 
after $24 \mathrm{~h}$ of incubation, when $A$. pisi cultures were post-treated with $20 \%$ acetone (Fig. 1). Without acetone post-treatment, esterase activity released after $24 \mathrm{~h}$ by $A$. pisi, was almost nil for all fatty acids used.

\section{Induction of esterase activity by juniperic acid}

When increasing concentrations of juniperic acid were used as sole carbon source, high esterase activity was released after $24 \mathrm{~h}$ by $A$. pisi, when cultures were post-treated with acetone (Fig. 2). No significant esterase activity was released without acetone post-treatment.

Fig. 2. Esterase activity released by A. pisi after $24 \mathrm{~h}$ of culture in media containing increasing concentrations of juniperic acids used as sole carbon source, followed or not by acetone posttreatment, $(\underline{I}$ : standard deviation)
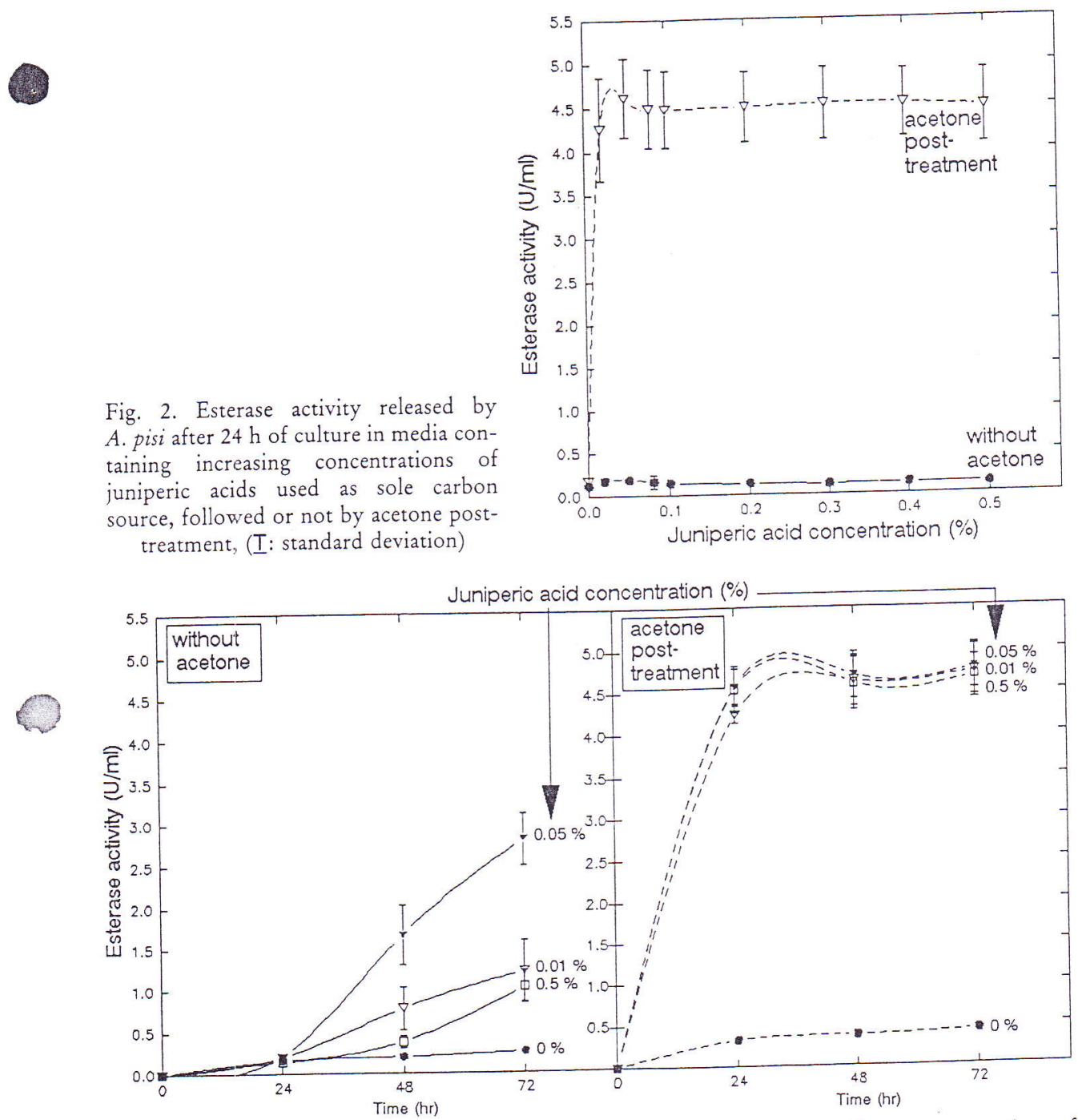

Fig. 3. Esterase activity released by $A$. pisi after culture in media containing different concentrations of Fig. juniperic acid used as sole carbon source,

J. Phytopathology, Bd. 136, Heft 3 
When the culture period in juniperic acid medium was extended up to $72 \mathrm{~h}$, the release of esterase activity increased, and was higher with $0.01 \%$ or $0.05 \%$ than with $0.5 \%$ juniperic acid. Without juniperic acid (control), no esterase activity was released (Fig. 3). Acetone post-treatment resulted in the similar release of esterase activity for the three concentrations of juniperic acid.

\section{Cutinase activity induced by juniperic acid}

The enzyme released by $A$. pisi grown in culture medium containing juniperic acid (with or without acetone extraction from the mycelium) showed cutinolytic (cutinase) activity, and was inhibited by adding DFP, a cutinase inhibitor, to the enzymatic reaction medium (Table 1).

Table 1

Cutinase activity of $A$. pisi, as measured by the method of microtitration of fatty acids released from cutin substrate ${ }^{1}$ )

\begin{tabular}{lc}
\hline \multicolumn{1}{c}{ Treatment } & Cutinase activity $(\mathrm{U} / \mathrm{ml})$ \\
\hline Control without lyophilized culture filtrate & 0.15 \\
Lyophilized culture filtrate & 0.60 \\
Lyophilized culture filtrate + DFP & 0.18 \\
Lyophilized acetone-treated mycelium filtrate & 0.84 \\
Lyophilized acetone-treated mycelium filtrate + DFP & 0.15 \\
\hline
\end{tabular}

1) A. pisi cultures grown for 15 days on juniperic acid medium, were filtered and the filtrate was collected. The mycelium was resuspended for $2 \mathrm{~h}$ in fresh mineral solution containing $20 \%$ acetone, and then filtered again. Both filtrates were dialysed, lyophilized and mixed with a cutin suspension for $24 \mathrm{~h}$, in the presence or not of $10 \mathrm{mM}$ of the cutinase inhibitor DFP. The released fatty acids were extracted in diethyl ether, dissolved in methanol, and microtitrated with $\mathrm{NaOH}$.

Inhibition of esterase activity by fatty acids

The addition of $0.05 \%$ fatty acids to cutin in the culture medium did not modify the low esterase activity released by $A$. pisi after 24 h. Post-treatment with acetone induced a large increase of the release of esterase activity by $A$. pisi grown on cutin alone (control), while addition of stearic acid to the cutin medium reduced the release of esterase activity by half. Addition of $0.05 \%$ of other fatty acids to cutin had little effect (Fig. 4).

Addition of $0.5 \%$ fatty acids to the cutin culture medium resulted in low esterase activity in all cases without acetone post-treatment. Post-treatment with acetone largely increased esterase release and reached almost the same level for cutin alone, or for cutin supplemented with palmitic, juniperic or 12-hydroxystearic acids. Incubation of $A$. pisi in cutin medium supplemented with $0.5 \%$ stearic acid, released only $1 / 3$ of the esterase activity released in the cutin alone control. When $0.5 \%$ ricinelaidic acid or ricinoleic acid was added to the cutin medium, release of esterase activity dropped to almost nil. 
$72 \mathrm{~h}$, $.05 \%$ terase imilar

ining owed cinase

d not with rown dium fatty

low with 1 for oxy$.5 \%$ lone sutin

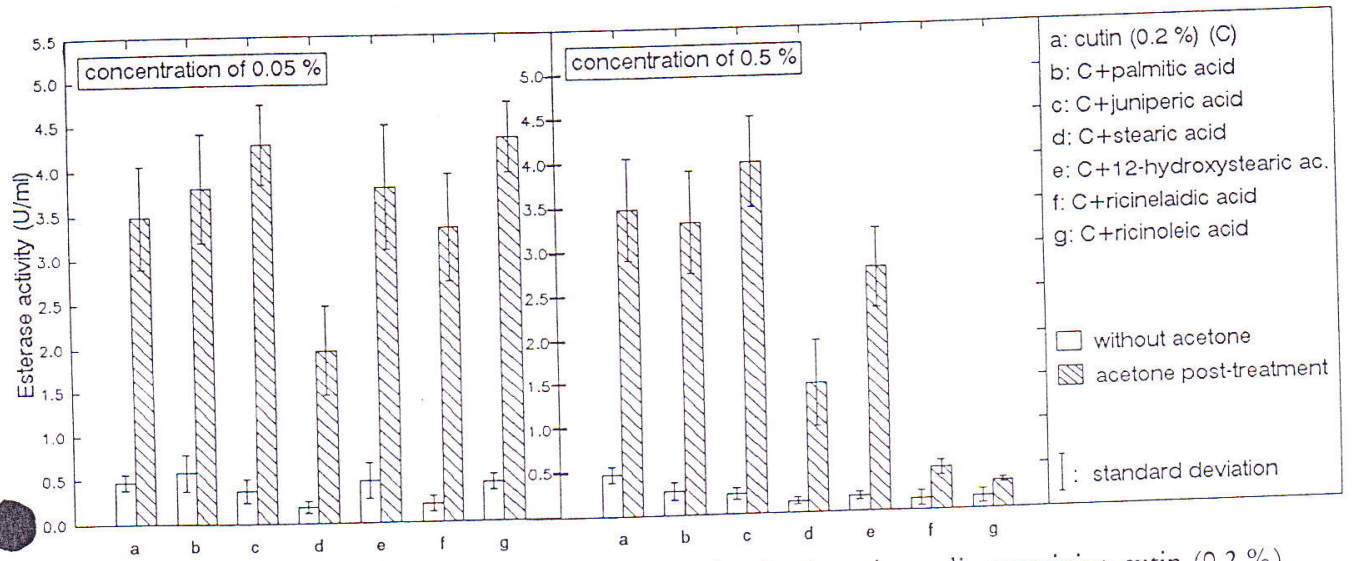

Fig. 4. Esterase activity released by $A$. pisi after $24 \mathrm{~h}$ of culture in media containing cutin $(0.2 \%)$ . $0.5 \%$ of different fatty acids, followed or not by acetone posttreatment

\section{Inhibition of esterase activity by ricinoleic acid}

After 24 h of culture, little esterase activity was released by $A$. pisi grown in cutin medium supplemented with increasing concentrations of ricinoleic acid (Fig. 5). Upon post-treatment with acetone, the release of esterase activity which was high at low cutin medium (up to $0.1 \%$ ) decreased sharply with increasing ricinoleic acid concentration, to reach almost nil with $0.4 \%$ and $0.5 \%$.

Fig. 5. Esterase activity released by A. pisi after 24 h of culture in media containing cutin $(0.2 \%)$ supplemented with increasing concentrations of ricinoleic acid, followed or not by acetone posttreatment, ( $\mathrm{I}$ : standard deviation)

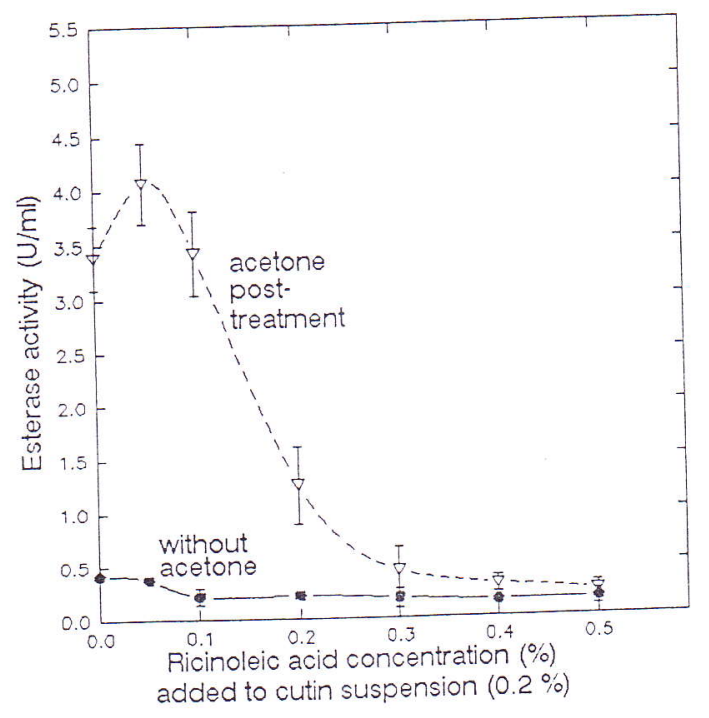

When the culture period was extended up to $72 \mathrm{~h}$, similar results were obtained (Fig. 6). 


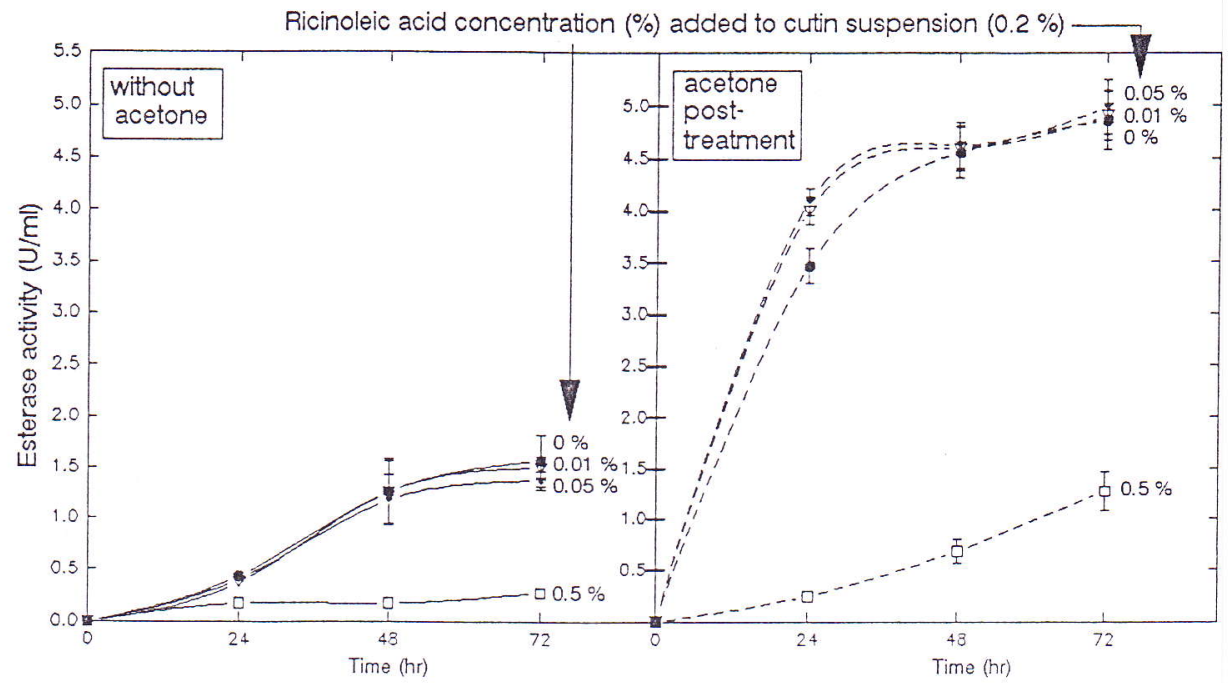

Fig. 6. Esterase activity released by $A$. pisi after culture in media containing cutin $(0.2 \%)$ supplemented with different concentrations of ricinoleic acid, followed or not by acetone post-treatment, (I: standard deviation)

Juniperic and ricinoleic acids as carbon source for $A$. pisi

Culture of $A$. pisi for $72 \mathrm{~h}$ in a medium containing $0.05 \%$ juniperic acid as carbon source, released an esterase activity which was enhanced by post-treatment with acetone. In contrast, when $0.5 \%$ ricinoleic acid was used as sole carbon source, $A$. pisi did not release a significant esterase activity. When supplemented to medium containing $0.05 \%$ juniperic acid, ricinoleic acid at $0.5 \%$ inhibited completely (without acetone) or strongly (with acetone posttreatment) the release of esterase activity (Fig. 7).

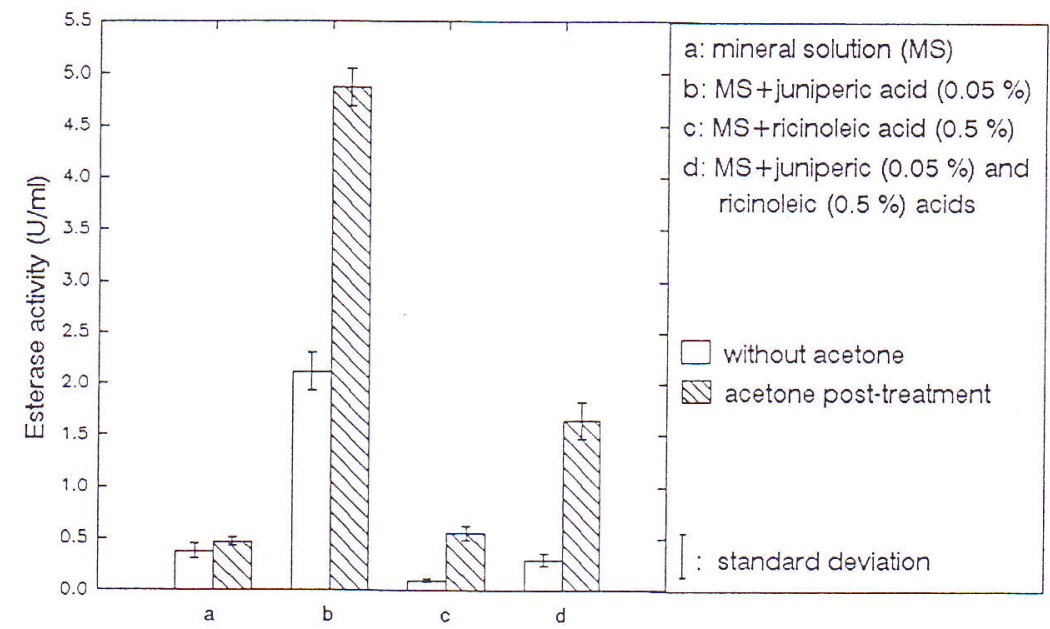

Fig. 7. Esterase activity released by $A$. pisi after $72 \mathrm{~h}$ of culture in mineral medium containing $0.05 \%$ juniperic acid and/or $0.5 \%$ ricinoleic acid, followed or not by acetone post-treatment 


\section{Discussion}

Cutinase has been usually induced by cultivating fungi on cutin as sole carbon source (KolatTUKUDY 1985, KölLER 1991). In the case of $F$. solani f. sp. pisi, cutinase was also induced by cutin fatty acids (LIN and KOLATTUKUDY 1978, Woloshuk and Kolattukudy 1986, Podila et al. 1988). In the present work, we used commercial fatty acids as carbon source for A. pisi, and showed that juniperic acid is a good inducer of the in vitro release of esterase activity by this fungus.

Using the method of microtitration of fatty acids released from cutin substrate, we confirmed that the enzymatic activity induced by juniperic acid (with or without acetone post-treatment) is indeed cutinase.

Little cutinase was released by $A$. pisi after $24 \mathrm{~h}$ of culture in a mineral medium supplemented with juniperic acid. Cutinase activity increased when the culture period was extended to $72 \mathrm{~h}$, but less cutinase was released in the medium containing $0.5 \%$ juniperic acid, than with $0.01 \%$ or $0.05 \%$. After acetone posttreatment, the level of released cutinase was the same with $0.01 \%, 0.05 \%$ or $0.5 \%$ juniperic acid. These results suggest that juniperic acid induced the synthesis of cutinase at all three concentrations, while the release of this enzyme was partially inhibited by $0.5 \%$ juniperic acid, and restored by post-treatment with acetone.

To study the possible inhibition of cutinase release, the mineral culture medium was supplemented with a mixture of cutin and commercial fatty acids. Ricinoleic and ricinelaidic acids at $0.5 \%$ strongly inhibited cutinase release, even after acetone post-treatment, but were without effect at $0.05 \%$.

Among all fatty acids tested, ricinoleic acid was the strongest inhibitor of cutinase release by $A$. pisi. At $0.5 \%$, it severely inhibited the release of cutinase induced by cutin or juniperic acid used as source of carbon, but was without effect at $0.01 \%$ or $0.05 \%$. This indicates that, in contrast to juniperic acid, ricinoleic acid might inhibit not only the release, but also the induction of the enzyme.

Our overall results suggest that some commercially available $\mathrm{C}_{16}$ and $\mathrm{C}_{18}$ fatty acids are able to induce or inhibit the in vitro release of cutinase by $A$. pisi, and so could play a role in the regulation of the fungal cutinase production during the process of infection of the host-plant.

We thank the "Administration Générale de la Coopération au Développement" (AGCD), Brussels, Belgium, for support to B. NASRAOUI.

\section{Literature}

BAKER, C. J., and D. F. BATEMAN, 1978: Cutin degradation by plant pathogenic fungi. Phytopathology $68,1577-1584$.

Y. HeNIS, 1985. Detection of cutinases and pectic enzymes during BASHAN, Y., Y. OHON, and Y. HeNIS, 1985: Detection of cutinases and pelogy $75,940-945$.
infection of tomato by Pseudomonas syringae pv. tomato. Phytopatholog

Dickman, M. B., and S. S. PatiL, 1986: A rapid and sensitive plate assay for
produced by plant parhogenic fungi. Phytopathology $76,473-475$. 
246 Nasraoui, Lepoivre and Semal, Effects of Commercial Fatty Acids on Cutinase Release

Kolattukudy, P. E., 1985: Enzymatic penetration of the plant cuticle by fungal pathogens. Ann. Rev. Phytopath. 23, 223-250.

KÖLLER, W., 1991: The plant cuticle: A barrier to be overcome by fungal plant pathogens. In: GARRY, T. C., and C. H. Harvey (eds), The Fungal Spore and Disease Initiation in Plants and Animals, pp. 219-246. Plenum Press, New York and London.

Laurent, J., 1982: Les méthodes de purification d'enzymes. In: Durand, G., et P. Mosan (eds), Les enzymes, production et utilisations industrielles, pp. 47-80. Gauthier-Villars, France.

Lin, T. S., and P. E. KolatTukUdy, 1978: Induction of a biopolyester hydrolase (cutinase) by low levels of cutin monomers in Fusarium solani f. sp. pisi. J. Bact. 133, 942-951.

Nasraoui, B., P. Leporvre, J. P. Barthelemy, and J. Semal, 1990: Evidence of cutinase activity released by Ascochyta pinodes and Ascochyta pisi. Mededelingen van de Faculteit van de Landbouwwetenschappen, Rijksuniversiteit Gent 55, 835-842.

Parkininen, E., E. OURA, and H. SuOmalainen, 1978: The esterases of baker's yeast. I. Activity and localization in the yeast cell. J. Inst. Brew. 84, 5-8.

Podila, G. K., M. B. Dickman, and P. E. Kolattukudy, 1988: Transcriptional activation of a cutinase gene in isolated fungal nuclei by plant cutin monomers. Science 242, 922-925.

Purdy, R. E., and P. E. Kolattukudy, 1975: Hydrolysis of plant cuticle by plant pathogens. Properties of cutinase I, cutinase II and nonspecific esterase isolated from Fusarium solani pisi. Biochemistry 14, 2832-2840.

Woloshuk, C. P., and P. E. KolatTukudy, 1986: Mechanism by which contact with plant cuticle triggers cutinase gene expression in the spores of Fusarium solanif. sp. pisi. Proc. Natl. Acad. Sci. USA 83, 1704-1708. 